\title{
Demokrasi dan Komodifikasi Perlindungan Kesehatan \\ Bagi Perempuan
}

Oleh:

\section{Derajad S Widhyharto}

\begin{abstract}
Abstrak
Seiring dengan euphoria reformasi politik, demokrasi dan demokratisasi pada tahun 2000-2005 mengalami peningkatan perhatian tetapi belum melekat kuat dalam sistem politik di daerah. Saat itu, isu kesehatan perempuan berpacu dengan kompetisi, partisipasi dan kebebasan. Kota Madiun menjadi salah satu arena kontestasi tersebut, resikonya demokrasi termodifikasi oleh dinamika sosial, politik dan pasar. Merespon hal tersebut, diperlukan upaya menggeser pendekatan kesehatan perempuan instrumental menuju pada pendekatan kesehatan perempuan substantif. Caranya memperkuat posisi subyek perempuan dalam perlindungan kesehatan perempuan hamil dan melahirkan.
\end{abstract}

Kata kunci: demokrasi, perlindungan, kesehatan, perempuan, komodifikasi

\begin{abstract}
As the euphoria of political reformation happens, democracy and democratization during 2000-2005 got more attention even it has not embedded in its local political system. At that time, women's health issues competed with issues of participation and Political freedom. Madiun city became one of its arena of contestation, the impact then democracy was commodified by social dynamic, politic and market. To respond these issues, it needs an effort to shift the approach which previously based on instrumental into more subtantif women's health approaches. One of its way is by strengthening the protection on pregnant and maternal womens as a subject.
\end{abstract}

Keywords : democracy, protection, health, women, comodification 
Jurnal Pemikiran Sosiologi Volume 1 No.1, 2012

Derajad S Widhyharto

Demokrasi dan Komodifikasi Kesehatan Perlindungan Kesehatan Bagi Perempuan

\section{A. Pendahuluan}

Bunga, seorang perempuan dari keluarga yang tidak mampu. Bunga tinggal di pinggiran Bengawan Madiun. Bunga datang ke Puskesmas Mangunharjo untuk memeriksakan kandunganya. Saat pemeriksaan pertama, usia kandungannya sudah empat bulan. Menurut diagnosis dokter, kandungan Bunga mempunyai masalah karena posisi bayi yang terbalik. Dokter menyarankan agar Bunga memeriksakan diri ke rumah sakit. Tapi setelah sampai rumah sakit, keluhan Bunga tentang posisi bayi tidak digubris, bahkan dokter berkata "..ah, itu biasa." Kemudian Bunga diberi vitamin dan obat penguat janin. Sesampai di rumah, Bunga stress dan kebingungan, kepada siapa lagi Bunga bisa mendapatkan informasi dan kepastian kesehatan jika sang dokter sudah mengatakan "biasa saja". Dengan kondisi seperti itu, kesehatan kandungan Bunga terganggu. Akhirnya ia mengalami keguguran. Ironisnya, saat pemeriksaan kandungan setelah keguguran sang dokter sekali lagi berkata "....ah itu biasa...." Bunga sebenarnya sangat marah tapi tidak berdaya. Diakhir pemeriksaan sang dokter bertanya, mana suamimu? Bunga menjawab, suami saya bekerja, dokter. Kalau bisa saya ketemu dengan suami ibu, saya ingin bicara soal kandungan ibu, tukasnya. Pada saat dokter mengatakan hal tersebut, Bunga baru sadar bahwa ia tidak berhak mendapat informasi kesehatan yang jelas dan benar, meskipun ia yang mengandung hanya karena ia seorang

perempuan. Dokter berasumsi bahwa yang dapat menerima informasi dan pengambil keputusan adalah laki-laki. Padahal ia tidak mungkin mengajak suaminya periksa ke dokter karena suaminya harus mencari nafkah. Kasus di atas merupakan salah satu contoh betapa perempuan dipinggirkan dan tidak punya hak atas hidupnya sendiri. Wacana eksistensi perempuan dengan segala kompleksitas persoalannya selalu menjadi perdebatan yang menarik dibicarakan oleh banyak kalangan. Salah satu alasan mengapa membicarakan permasalahan perempuan menjadi penting, adalah adanya ketidakadilan yang bersumber pada permasalahan gender. Perbedaan gender sesungguhnya tidaklah menjadi masalah sepanjang tidak melahirkan ketidakadilan gender (gender inequalities). Namun, yang menjadi persoalan ternyata perbedaan gender telah melahirkan berbagai bentuk ketidakadilan, baik bagi kaum laki-laki dan terutama terhadap kaum perempuan. Ketidakadilan gender merupakan sistem dari struktur yang membuat kaum laki- laki maupun perempuan menjadi korban dalam sistem tersebut. Untuk memahami bagaimana perbedaan gender menyebabkan ketidakadilan gender, dapat dilihat dari berbagai manifestasi ketidakadilan yang ada, misalnya: marginalisasi atau proses pemiskinan ekonomi, subordinasi atau anggapan tidak penting dalam keputusan politik, pembentukan stereotipe atau melalui pelabelan negatif, kekerasan, beban kerja lebih panjang dan lebih banyak, serta lemahnya sosialisasi ideologi nilai peran gender. Manifestasi ketidakadilan gender tidak bisa dipisahpisahkan, karena saling berkaitan dan berhubungan, saling mempengaruhi secara dialektis. ${ }^{1}$ Gambaran kompleksitas dan luasnya persoalan perempuan telah menjadikan isu perempuan sebagai isu nasional bahkan menjadi isu global. Pertanyaannya

${ }^{1}$ Lihat Mansour Fakih, 2001, Analisis Gender dan Transformasi Sosial. Yogyakarta: Pustaka Pelajar. Hlm..12 
Jurnal Pemikiran Sosiologi Volume 1 No.1, 2012

Derajad S Widhyharto

Demokrasi dan Komodifikasi Kesehatan Perlindungan Kesehatan Bagi Perempuan

kemudian mengapa perempuan bukan ibu, Pemerintah Indonesia sudah meratifikasi CEDAW (Convention on the Elimination of All Forms of Discrimination against Women). karena Indonesia tidak punya undang-undang perlindungan terhadap kaum perempuan, maka pemerintah-atas nama negara-tidak mau melaksanakan karena berlawanan dengan kultur. Sebab lain, identifikasi perlindungan perempuan hamil dan melahirkan seharusnya untuk semua perempuan bukan pada ibu saja yang notabene dibatasi oleh perempuan yang sudah menikah. Jadi terjadi diskriminasi terkait dengan status perempuan. Ini merupakan persoalan substansial yang sampai saat ini belum ada jalan keluarnya. Sebagaimana kita tahu, Konferensi Internasional tentang Kependudukan dan Pembangunan (ICDP =International Conference on Population and Development) di Kairo, 1994, telah tegas menyebutkan bahwa hak reproduksi merupakan bagian dari hak asasi. Kesepakatan dalam konferensi tersebut menyatakan bahwa "laki-laki dan perempuan memiliki hak memperoleh standar tinggi dalam pelayanan, informasi, bebas dari diskriminasi, ancaman dan kekerasan dalam kesehatan reproduksi dan kesehatan seksual". Sehingga sudah seharusnya negara memikul tanggung jawab untuk melindungi hak-hak warga negaranya di bidang pelayanan kesehatan perempuan (Sukmaningsih, dkk, 2003:37).

Ketidakpedulian negara terhadap perempuan dapat dilihat, misalnya, pada temuan Kementrian Negara Pemberdayaan Perempuan. Ada dua perundangan di bidang kesehatan yang bias gender di Kementrian tersebut, yakni: pertama, UU No.10/1992 tentang
Perkembangan Kependudukan dan pembangunan Keluarga Berencana, pada pasal 44 ayat (1) huruf a dan $b$ yang berkenaan dengan penggunaan alat, obat, dan cara pengaturan kehamilan yang dilakukan atas petunjuk dan atau tenaga kesehatan. Keterbatasan pengetahuan tenaga kesehatan akan gender dan dengan dalih program pemerintah, program Keluarga Berencana seolah-olah hanya diperuntukan bagi kaum perempuan. Selanjutnya yang kedua, UU No.23/1992 tentang kesehatan pada pasal 15 ayat (2) huruf c yang berkenaan dengan tindakan medis terhadap ibu hamil yang tidak dapat dilakukan tanpa persetujuan yang bersangkutan, suami atau keluarganya. ${ }^{2}$ Uraian tersebut memperlihatkan ketidakberdayaan perempuan dalam mengambil keputusan atas kesehatannya sendiri. Ketidakberdayaan masih berlanjut di bidang pendidikan, pada level nasional tingkat pendidikan perempuan dibandingkan dengan laki-laki sangat jauh tertinggal. Sebanyak 39 persen perempuan tidak sekolah, hanya 13 persen yang lulus sekolah lanjutan pertama (SLTP) dan kurang dari lima persen lulus perguruan tinggi. Meskipun ada kecenderungan semakin kecilnya kesejangan gender dalam pendidikan, namun angka buta huruf perempuan masih di atas laki-laki. Hingga tahun 2003, penduduk perempuan buta aksara usia 15 tahun ke atas mencapai 13,84 persen. Sedangkan penduduk laki-laki usia 15 tahun ke atas yang buta huruf sebesar 6,52 persen (Kompas, 13/05/05).

Di Indonesia upaya perlindungan dan pelayanan kesehatan perempuan hamil dan melahirkan belum dilakukan secara optimal, hal ini terlihat dari angka kematian ibu dan bayi yang masih cukup tinggi. 
Jurnal Pemikiran Sosiologi Volume 1 No.1, 2012

Derajad S Widhyharto

Demokrasi dan Komodifikasi Kesehatan Perlindungan Kesehatan Bagi Perempuan

Angka kematian ibu melahirkan di Indonesia tidak jelas datanya. Angka terendah yang sering digunakan adalah data resmi, 373 per 10.000 kelahiran hidup. Organisasi Kesehatan Dunia menyodorkan angka 470 per 100.000 kelahiran. Data lain lagi 650 per 100.000 kelahiran. Namun, menggunakan angka mana pun, angka kematian ibu di Indonesia tergolong kedua tertinggi di negaranegara yang mayoritas penduduknya beragama Islam. Yang pertama adalah Afghanistan dengan 1.700 per 100.000 kelahiran hidup, disusul Indonesia, kemudian Pakistan (Kompas, 15/12/2003). Di samping itu, orientasi pelayanan yang masih diskriminatif kaya-miskin dan komersial semakin memperburuk kondisi pelayanan kesehatan perempuan. Kondisi tersebut dibuktikan dengan semakin terpuruknya peringkat Human Development Index (HDI, 2002) yang saat itu mencatat Indonesia pada peringkat 112 dari 175 keseluruhan peringkat yang ada. Paradoks kesehatan sebagai hak dan komoditi merupakan hal yang sangat krusial untuk ditelaah lebih lanjut. Munculnya dikotomi hak, yang direpresentasikan oleh UDHR- universal declaration of human right, dan komoditas, yang direpresentasikan dengan eksistensi WTO (World Trade Organization), tentu saja terkait dengan proses industrialisasi di seluruh dunia. Tarik ulur antara kebijakan komersialisasi dan idealisme perlindungan kesehatan memang bukan hal baru lagi. Demikian pula di Indonesia, jika diamati langsung untuk memahami persoalan tersebut diperlukan sebuah keberpihakan yang jelas terhadap pembuatan kebijakan pelayanan kesehatan. Tentu saja, keberpihakan idealisme pelayanan kesehatan harus lebih diutamakan untuk mendapatkan pelayanan kesehatan optimal. Asumsi bahwa modal diperlukan dalam mengelola pelayanan kesehatan tidak salah, tetapi bahwa modal bisa digunakan untuk mendukung peningkatan dan pengembangan pelayanan kesehatan akan lebih bisa dipahami. Berbagai persoalan akan muncul apabila logika uang sudah merasuk dalam sistem pelayanan kesehatan.

Kondisi sosial dan ekonomi politik Indonesia telah terkooptasi dengan logika kapital yang kuat. Bahkan jika diamati lebih jauh, konsep pelayanan kesehatan masyarakat yang direpresentasikan oleh eksistensi Puskesmas sebagai tempat pertolongan pertama dan berobat yang bisa diakses oleh masyarakat miskin sekarang sudah tidak lagi berfungsi secara efektif melayani masyarakat miskin lagi. ${ }^{3}$ Keadaan menjadi terbalik mereka yang mampu/kaya justru memanfaatkan pelayanan kesehatan yang disubsidi oleh pemerintah, hal ini menunjukkan logika uang atau orientasi uang (money oriented) sudah dikenal dalam setiap pelayanan kesehatan yang dilakukan oleh Puskesmas. Hal tersebut diperkuat dengan pernyataan bahwa "Eksistensi Perda tentang retribusi telah mengubah semangat pelayanan kesehatan yang berorientasi pada proses menjadi berorientasi output". Tentu saja, hal ini berpengaruh terhadap perkembangan paradigma pelayanan kesehatan. Alhasil, pasien enggan memeriksakan kesehatannya karena pelayanan yang tidak optimal dan mahalnya biaya pelayanan termasuk harga obat. Argumentasi tersebut cukup memberi penjelasan bahwa pelayanan kesehatan perempuan hamil dan melahirkan merupakan kebijakan krusial yang

${ }^{3}$ Lihat data akses masyarakat terhadap pelayanan kesehatan (SUSENAS 2001). 
Jurnal Pemikiran Sosiologi Volume 1 No.1, 2012

Derajad S Widhyharto

Demokrasi dan Komodifikasi Kesehatan Perlindungan Kesehatan Bagi Perempuan

harus direspon serta dianalisis secara periodik dan komprehensif. Ini akan membuat ekses negatif dari pertentangan antara hak memperoleh pelayanan dan komoditas yang berorientasi pada kapital dapat dipetakan secara jelas.

Masuknya sektor kapital atau modal dalam ruang pelayanan kesehatan perempuan tersebut semakin diperkuat dengan adanya kebijakan desentralisasi yang sesuai dengan semangat otonomi daerah saat itu. Dengan dalih mengembangkan potensi dan peningkatan pendapatan daerah puskesmas dipaksa mempunyai fungsi sebagai pengumpul dana fundraising. Ini yang kemudian memunculkan isu privatisasi Puskesmas yang oleh beberapa daerah sudah dibuatkan Peraturan Daerahnya. Pada kenyataannya, dengan memberikan peluang kapital masuk ke dalam ruang publik justru semakin mengukuhkan juga eksistensi pengambilalihan atau take over yang dilakukan pemodal untuk menguasai pelayanan kesehatan. Jika hal tersebut terjadi, maka bisa dipastikan berbagai kemahalan pelayanan kesehatan akan mengikuti seiring dengan argumentasi demand dan supply. Secara makro uraian di atas merepresentasikan urgensi dan kompleksitas persoalan kesehatan perempuan. Berangkat dari asumsi itu tidaklah berlebihan jika persoalan kesehatan, khususnya yang terkait dengan kesehatan perempuan perlu mendapat perhatian secara lebih konkrit.

Tidak jauh berbeda dengan konteks nasional, dalam konteks lokal, Kota Madiun juga mempunyai cerita tersendiri yang terkait dengan persoalan pelayanan kesehatan perempuan. Diawali dengan asumsi bahwa pembangunan yang dinilai pesat dan merata di Pulau Jawa seharusnya berimplikasi positif pada pelayanan kebutuhan dasar masyarakat yang semakin membaik. Ternyata fakta di lapangan berbicara lain, tingkat pendidikan perempuan yang rendah, dan ketidakjelasan akses perempuan terhadap informasi tentang pelayanan kesehatan dasar, menjadikan pengetahuan perempuan akan berbagai haknya terhadap kebutuhan kesehatan kurang. Sebagai ilustrasi dalam hal pendidikan, tak lebih dari 64,5 persen penduduk berusia 10 tahun hanya tamat SD, tidak tamat SD, dan tidak bersekolah sama sekali, 43,9 persen di antaranya buta huruf dan 79,6 persen-nya adalah perempuan. Rendahnya tingkat pendidikan perempuan berpengaruh kepada pemahaman mereka mengenai kesehatan sehingga memperlemah posisi mereka dalam hubungan antar individu maupun sosial, seperti dengan pasangan dan orang lain (Kompas,14/07/2003).

Kondisi ini, tentu saja berpengaruh pada persepsi masyarakat terhadap pelayanan kesehatan perempuan. Sebagai hasilnya, tingkat kematian ibu dan bayi masih membayangi kehidupan masyarakat Kota Madiun. Angka kematian Ibu dan bayi telah memberikan gambaran konkrit tentang persoalan kesehatan perempuan di Kota Madiun.

Berdasarkan hasil registrasi penduduk tahun 2003, jumlah penduduk Kota Madiun sebanyak 192.807 terdiri dari 92.724 laki- laki dan 100.083 perempuan. Dengan tingkat kepadatan penduduk yang mencapai sekitar 5.802 jiwa/Km2. Rasio jenis kelamin 92,65 persen yang berarti setiap 100 orang penduduk perempuan terdapat 93 laki-laki, sehingga jumlah penduduk perempuan lebih banyak dibandingkan laki-laki. Selanjutnya, hal lain yang menarik adalah stagnasi angka kematian bayi dan ibu yang masih cukup besar, yaitu angka kematian 
Jurnal Pemikiran Sosiologi Volume 1 No.1, 2012

Derajad S Widhyharto

Demokrasi dan Komodifikasi Kesehatan Perlindungan Kesehatan Bagi Perempuan

bayi tahun 2003; 18 bayi per 1000 kelahiran sedangkan angka kematian ibu tahun 2003; 3 ibu per 1000 persalinan. ${ }^{4}$ Angka tersebut tidak jauh berbeda dari tahun sebelumnya 2002 dan 2001. Selain itu, perkembangan kesehatan di Kota Madiun menunjukkan terjadi peningkatan angka kasus balita buruk dari $1,33 \%$ menjadi 3,3\%, rendahnya gizi ibu dan bayi, serta rentannya keselamatan ibu hamil dan ibu pasca melahirkan. Keselamatan ibu dan bayi yang baru lahir tidak semata-mata karena

persoalan medis saja, tetapi juga sangat bergantung pada pengetahuan masyarakat dan keluarga tentang pentingnya kesehatan lingkungan, makanan bersih dan bergizi, serta penanganan dan perlakuan terhadap masa kehamilan dan pasca melahirkan (PROPEDA Tahun 2001-2005). Kondisi tersebut semakin mengukuhkan absurditas konsep perlindungan dan pelayanan kesehatan perempuan di Kota Madiun. Hal inilah yang menjadikan Kota Madiun dianggap cukup relevan menjadi lokasi penelitian saat itu. Selanjutnya, hal tersebut juga digunakan untuk melihat tingkat keseriusan pemerintah setempat dalam melakukan perubahan kebijakan. Dan sekaligus mendorong pembuatan kebijakan lokal yang sesuai konteks pelayanan kesehatan yang sensitif gender.

\footnotetext{
${ }^{4}$ Diolah dari Data Dinas Kesehatan Kota Madiun

${ }^{5}$ Lihat Sorensen, Georg, Demokrasi dan demokratiasi, Proses dan Prospek dalam Sebuah Dunia yang Sedang Berubah, Pustaka Pelajar, Yogyakarta, 2003.

6 Terjadi pergeseran paradigma pembangunan yang memicu peranan perempuan dalam pembangunan dan sekaligus menjadi acuan pembangunan di berbagai negara, yaitu, dari production-centered development menuju people-centered development. Kalau pembangunan yang berorientasi produksi meletakkan nilai produksi dan produktivitas pada tempat yang utama, meskipun dengan konsekuensi mendegradasikan manusia sebagai utility-maximizer atau profit-maximixer, dan
}

\section{B. Demokrasi dan Pembangunan Tercerabut}

Kesehatan sebagai komoditas merupakan bagian tidak terpisahkan dari perkembangan sistem demokrasi di Indonesia. Demokrasi berasal dari bahasa Yunani: demos yang berarti rakyat dan kratos yang berarti pemerintahan. Demokrasi (liberal) menurut Georg Sorensen adalah liberal dahulu (bertujuan untuk membatasi kekuasaan negara atas masyarakat sipil dan demokrasi kemudian (bertujuan untuk meciptakan struktur yang akan mengamankan mandat rakyat untuk para pemegang kekuasaan negara). ${ }^{5}$ Banyak definisi-definisi lain tentang demokrasi, termasuk berbagai jenis demokrasi yang berkembang sejak kelahirannya di Yunani. Maksud tulisan ini tidak untuk memperdebatkan definisi dan perkembangan demokrasi yang kemudian menjadi kredo suci hampir semua negara di dunia dalam rangka perubahan tata pemerintahan suatu negara ke arah yang lebih 'baik'. Namun kita akan melihat bagaimana proses demokrasi dan demokratisasi membawa dampak besar pada perempuan terkait dengan pelayanan kesehatan di Indonesia umumnya dan lebih khusus lagi Kota Madiun.

Proses pembangunan di Indonesia sebagaimana juga terjadi dengan pembangunan di negara-negara dunia ketiga lainnya, dalam wacana pembangunan dapat dipahami dari beberapa perspektif. ${ }^{6}$ Pada

menempatkan manusia sebagai pelengkap faktor produksi semata-mata, maka pembangunan yang berorientasi kemanusiaan bertujuan untuk mengaktualisasikan nilai-nilai kemanusiaan, seperti respect, identitas, authencity, kemandirian, kebebasan, harga diri, dan sebagainya. Penerapan people-centered development paradigm tidak saja tidak mungkin mengabaikan lebih dari separuh umat manusia, akan tetapi juga mengungkap adanya kecenderungan masyarakat di semua negara menempatkan perempuan pada posisi sekunder atau sub-ordinasi (Preston,1996:h.83) 
Jurnal Pemikiran Sosiologi Volume 1 No.1, 2012

Derajad S Widhyharto

Demokrasi dan Komodifikasi Kesehatan Perlindungan Kesehatan Bagi Perempuan

dasarnya pembangunan yang saat ini berlangsung dipandang sebagai suatu proses perkembangan kapitalisme dalam bentuk dan mekanisme yang beragam. Pertanyaan krusial yang masih relevan dipertanyakan, apakah integrasi dunia ketiga dalam suatu dunia kapitalis global akan memberikan kesempatan pada negara-negara dunia ketiga untuk berkembang ataukah justru akan melembagakan keterbelakangannya.

Pertanyaan berikutnya yang perlu diajukan adalah: apa hubungan kapitalisme dan demokrasi? Demokrasi mensyaratkan kompetisi, pastisipasi dan kebebasan politik. 7 Setelah tumbangnya rezim otoritarian pada tahun 1998, Indonesia memasuki babak baru demokrasi. Partisipasi dan kebebasan politik meningkat tajam, Hal ini bisa dilihat dari pemilu multi partai yang berlangsung tahun 1999 yang diikuti hampir 50 partai politik. Partai-partai itu berkompetisi memperebutkan kursi anggota dewan. Sejalan dengan itu, babak baru demokrasi itu juga membuka pintu bagi perusahaan multinasional masuk, termasuk dalam bidang kesehatan. Untuk memuluskan kapitalisme global masuk semakin jauh, maka peran negera yang direpresentasikan oleh pemerintah harus dipersempit. Pemerintah harus memberi kesempatan masyarakat untuk berpastisipasi dalam pembangunan. Monopoli secara tegas ditolak dalam demokrasi karena menutup ruang kompetisi yang akan menutup kemungkinan masyarakat menjadi bagian dalam proses pembangunan. Artinya, demokrasi membolehkan masyarakat (kapital) mengelola sektor-sektor yang terkait 'hajat hidup

${ }^{7}$ Lihat Hans-Jorgen Nielsen grouped these eight in a similar way in Den Chilenske Transitionproces (Chilean process of transition)(Aarhus: University Aarhus, institute of political science, 1991), hal 5 dalam Sorensen, Georg, Demokrasi dan orang banyak' yang selama ini dipegang oleh negara, termasuk dalam hal pelayanan publik. Dalam perspektif yang lebih liberal, kehadiran negara (yang direpresentasikan oleh pemerintah) hanya diperlukan untuk menjaga keamanan8. Fungsi utama pemerintah hanyalah fungsi untuk menjaga keamanan ${ }^{8}$ dan ketertiban serta melakukan kontrol dalam masyarakat. Sementara fungsi lain sepenuhnya menjadi wewenang masyarakat. Dengan kalimat yang lebih terbuka, biarlah mekanisme pasar yang menentukan. Argumentasinya, dengan tingkat kompetisi yang tinggi pasti pelayanan akan semakin baik.

Privatisasi BUMN (Badan Usaha Milik Negara) yang terkait dengan hajat hidup orang banyak yang menguasai sumberdaya alam, air, dan kemungkinan ke depan udara merupakan bagian dari upaya penyempitan peran Negara. Sementara sektor pelayanan publik yang semula dikelola sepenuhnya, kemudian diserahkan ke pihak swasta. Yang terjadi kemudian sektor-sektor penting yang terkait langsung dengan kesejahteraan rakyat menjadi lahan subur bagi tumbuh kembangnya kapitalisme, termasuk pelayanan kesehatan bagi perempuan. Dengan menggunakan cara pandang kompetisi, partisipasi dan kebebasan kita akan melihat lebih jauh bagaimana demokratisasi pelayanan kesehatan memberikan efek buruk pada perempuan, khususnya perempuan miskin.

\section{Relasi Demokrasi, Perlindungan dan Komodifikasi}

demokratiasi, Proses dan Prospek dalam Sebuah Dunia yang Sedang Berubah, Pustaka Pelajar, Yogyakarta, 2003.

8 Lihat Pratikno, Fungsi-Fungsi Pemerintahan, Makalah “Pendalaman Materi Bidang Tugas DPRD”, 1997/1998 
Jurnal Pemikiran Sosiologi Volume 1 No.1, 2012

Derajad S Widhyharto

Demokrasi dan Komodifikasi Kesehatan Perlindungan Kesehatan Bagi Perempuan

Mengacu pada pandangan Sorensen bahwa demokrasi bertujuan untuk menciptakan struktur yang akan mengamankan mandat rakyat untuk para pemegang kekuasaan negara. Kita harus melihat lebih jauh kondisi yang berkembang-meminjam istilah Sorensen-sesungguhnya demokrasi yang berkembang di Indonesia adalah demokrasi yang lemah dan tidak solid. Hal ini ditandai dengan kepemimpinan politik yang tidak mempunyai landasan moral dan legimitasi ideologi yang dibutuhkan agar mereka dipatuhi oleh masyarakat

dan birokrat. ${ }^{9}$ Pemerintahan yang kuat bukan berarti pemerintahan yang otoriter. Pemerintahan yang kuat memiliki birokrasi yang efisien dan tidak korup, memiliki elit politik yang berkemauan dan mampu memberikan prioritas pada pembangunan ekonomi dan kebijakan yang dirancang dengan baik untuk mencapai tujuan pembangunan. ${ }^{10}$ Salah satu tujuan dari pembangunan di Indonesia adalah mensejahterakan rakyat sebagaimana yang diamanatkan dalam konstitusi.

Jika berpegang pada pandangan Sorensen, terkait dengan konteks pelayanan kesehatan di Indonesia umumnya dan Kota Madiun khususnya, yang dimaksud struktur yang mengamankan mandat rakyat adalah pasar (kapital). Kompetisi yang diharapkan menumbuhkan persaingan yang sehat adalah kompetisi yang terjadi di wilayah kapital. Perusahaan multi-nasional saling berlomba memperebutkan lahan subur pelayanan kesehatan perempuan hamil dan melahirkan. Hal ini terjadi karena peran pemerintah telah diperkecil hanya sebatas fungsi kepolisian yang menjaga ketertiban

${ }^{9}$ Lihat Sorensen, Georg, Demokrasi dan demokratisasi, Proses dan Prospek dalam Sebuah Dunia yang Sedang Berubah, Pustaka Pelajar, Yogyakarta, 2003 dan keamanan. Negara telah berhasil dijinakkan oleh kapital. Dalam arti yang lebih luas, fungsi kepolisian untuk mengamankan kapital-perusahaan multi-national yang bergerak di bidang kesehatanmelakukan penetrasi pasar ke tingkat yang paling bawah sekali pun. Perusahaan multi-nasional tidak berjalan sendiri dalam upaya mencapai itu, mereka menggandeng pemerintah untuk mempermudah penetrasi pasar.

Dalam konteks pelayanan kesehatan di Kota Madiun, kita bisa melihat dua elemen besar ini bersinergi dalam menghapuskan peran dukun bayi yang dianggap sebagai rival atau saingan bidan maupun dokter. Modernisasi bidang pelayanan kesehatan memang memberi dampak yang luas diantaranya: semakin canggihnya teknologi kedokteran, berkembangnya infrastruktur pelayanan kesehatan, dan semakin banyaknya ahli medis dan kedokteran. Hal tersebut juga di dukung oleh pesatnya industri kesehatan dapat dilihat dalam perkembangan industri farmasi di Indonesia, setidaknya ada 205 produsen obat yang terdaftar oleh pemerintah. Obat yang diproduksi tersebut didistribusikan 2.463 perusahaan dan 5.250 unit apotek, 5.625 unit toko obat. Adapun nilai ekspor obat-obatan tersebut mencapai 120 juta dollar AS per tahun, sedangkan nilai impor bahan baku, obat dan teknologi tinggi sebesar 300-500 juta dollar AS per tahun (Kompas, 6/08/05). Sedangkan implikasi negatif yang dirasakan oleh masyarakat saat ini adalah semakin besarnya biaya pelayanan kesehatan karena tuntutan kecanggihan teknologi dan segmentasi pelayanan kesehatan sebagai akibat dari tidak

10 Ibid. 
Jurnal Pemikiran Sosiologi Volume 1 No.1, 2012

Derajad S Widhyharto

Demokrasi dan Komodifikasi Kesehatan Perlindungan Kesehatan Bagi Perempuan

adanya standar pelayanan yang sama. Bagi perempuan hamil dan melahirkan kondisi tersebut semakin memperberat beban yang harus dipikul perempuan, setelah proses persalinan yang menyakitkan, perempuan juga harus menanggung besarnya biaya persalinan itu sendiri. Apabila perempuan tersebut memilih pelayanan yang murah tentu saja, pelayanannya pun akan berbeda pula. Padahal jika mau jujur dukun sebenarnya bisa dilatih untuk membantu persalinan masyarakat yang tidak bisa menjangkau fasilitas kesehatan.

Namun, ini tentu tidak bisa dilepaskan dari pemahaman perlindungan yang memang masih simpang siur diintepretasikan dalam kesehatan perempuan. Masyarakat awam menganggap perlindungan sama dengan "asuransi" pada umumnya. Tentu saja pemaknaannya sangat berbeda, jika asuransi lebih merujuk pada perlindungan terhadap pelayanan kesehatan dan sifatnya yang berorientasi bisnis. Maka, perlindungan kesehatan perempuan hamil dan melahirkan merujuk pada upaya pelayanan, perawatan kesehatan perempuan hamil sampai dengan melahirkan. Di Kota Madiun, pemahaman perlindungan perempuan hamil dan melahirkan juga masih dipahami seputar pelayanan fisik kesehatan perempuan semata yakni, ketersediaan bidan, fasilitas persalinan, dan berbagai obatobatan. Padahal esensi perlindungan sebenarnya adalah bagaimana menjaga perempuan hamil dan melahirkan bebas dari berbagai penyakit maupun persoalan kandungan sampai dengan perempuan tersebut melahirkan dengan selamat.

Persoalan kemudian banyak muncul manakala perlindungan diartikan sebuah larangan dalam kesehatan perempuan. Hasil wawancara triangulasi mengemuka banyak ditemui upaya perlindungan identik dengan larangan yang diberlakukan dokter maupun paramedis serta bidan terhadap perempuan hamil dan melahirkan. Larangan tersebut meliputi penggunaan obat-obatan tradisional, termasuk berobat ke dukun bayi. Dukun bayi tidak lagi punya tempat dalam kehidupan masyarakat miskin, lebih-lebih dalam industri kesehatan yang cepat, efisien, dan higienis untuk melakukan perlindungan dan pelayanan kesehatan perempuan hamil dan melahirkan. Higienis merupakan kampanye besar negara dan perusahaan obat multi-nasional untuk menyingkirkan dukun bayi.

Asumsi bahwa pelayanan kesehatan adalah isu public commodity, program sosial, Verliest Post (pembiayaan yang tidak memberi dampak balik dari segi ekonomi) ternyata tidak benar. Pelayanan kesehatan khususnya pelayanan kesehatan perempuan hamil melahirkan ternyata merupakan tambang emas bagi penyelenggara pelayanan kesehatan saat ini, bahkan sekarang sudah masuk ke isu private commodity. Ini terlihat dari berbagai ketergantungan perempuan hamil dan melahirkan terhadap susu, obat-obatan, teknologi kedokteran dan tenaga kesehatan. Maka bisa dipastikan yang diperoleh perempuan bukanlah sebuah standar pelayanan maupun perlindungan kesehatan yang optimal. Ironisnya, bagaimana sebuah perlindungan akan dilakukan jika perempuan masih menghadapi banyak "larangan", bahkan sifat eksternalitas perempuan hamil dan melahirkan telah menjadikan perempuan tidak mempunyai pilihan akan kesehatannya sendiri. Misalnya; keharusan operasi cesar dengan alasan yang tidak jelas, resep dokter 
Jurnal Pemikiran Sosiologi Volume 1 No.1, 2012

Derajad S Widhyharto

Demokrasi dan Komodifikasi Kesehatan Perlindungan Kesehatan Bagi Perempuan

yang menggunakan obat-obat tertentu yang mahal dan sebagainya.

Absurditas pelayanan kesehatan untuk perempuan hamil dan melahirkan semakin menjauhkan bara dari kayu saat pemerintah mengenakan biaya retribusi pada Puskesmas, Dokter dan Paramedias sebagai peningkatan pendapatan daerah (PAD). Berdasarkan Perda Nomor 14/2003 Kota Madiun yang mewajibkan kalangan profesi kesehatan membayar retribusi kepada Pemerintah Kota Madiun sebagai konsekuensi kegiatan profesi yang mereka lakukan. Meski sudah setahun disosialisasikan gagasan itu dilontarkan, tak urung penerapan Perda tersebut mengagetkan pekerja medis dan paramedis (Jawa Pos, 21/08/03).

Di satu sisi, kebijakan tersebut lebih mewakili kepentingan Pemerintah Kota Madiun untuk meningkatkan pendapatan daerah, sementara tuntutan pembangunan infrastruktur kesehatan yang memerlukan banyak dana dan tidak bisa ditawar lagi. Ironisnya, dalam pelaksanaannya orientasi pelayanan kesehatan justru berujung pada prioritas pembangunan fisik. Alhasil, kesenjangan antara substansi kesehatan dengan pembangunan fisik kesehatan menjadi timpang.

Kesenjangan diawali dari berbagai variasi persoalan yang muncul diseputar kebijakan kesehatan itu sendiri. Sebagai contohnya, sebut saja status gizi anak balita. Jumlah anak balita di Kota Madiun tahun 2003 sebanyak 10.132 anak dan seluruhnya telah memiliki Kartu Menuju Sehat (KMS). Jumlah anak balita terbanyak di wilayah Puskesmas Oro-oro Ombo 2.878 anak, puskesmas Banjarejo 2.351 anak, Puskesmas Manguharjo 2.039 anak, Puskesmas Demangan 1.822 dan Puskesmas Patihan sebanyak
1.042 anak. Adapun analisis status gizi anak balita menunjukkan bahwa; 1) balita dengan status gizi lebih sebanyak 512 anak (6,10\%), 2) balita dengan status gizi baik sebanyak 5.411 anak $(64,46 \%)$, balita dengan status gizi kurang 1.768 anak $(21,06 \%)$ dan status gizi buruk sebanyak 280 anak $(3,34 \%)$.

Kesenjangan terjadi manakala standar nasional untuk kelompok balita dengan status gizi buruk dalam suatu wilayah tidak boleh lebih atau sama dengan 1\% sedangkan balita gizi kurang tidak boleh lebih atau sama dengan 20\%. Apabila didapatkan keadaan melebihi standar yang ditentukan maka analisisnya termasuk masalah berat. Berdasarkan kondisi tersebut jelas bahwa status gizi balita di Kota Madiun termasuk yang mempunyai masalah berat. Tentu saja hal tersebut bertolak belakang dengan kebijakan pembangunan kesehatan yang telah dibuat.

Absurditas pelayanan kesehatan yang seperti itu telah ikut mendorong lahirnya wacana dikotomi dan komodifikasi perlindungan kesehatan perempuan. Komodifikasi dimaksudkan pada upaya melihat segala sesuatu yang bisa mendatangkan profit atau bisa dijual. Komodifikasi melahirkan dua efek, yaitu: Pertama, usaha diganti dengan kapital (uang), segala macam usaha dapat diganti dengan kapital termasuk usaha negatif maupun positif untuk mendapatkan sesuatu. Efek kedua, timbul anggapan bahwa semua dari yang terburuk sampai yang terbaik harus bisa menghasilkan kapital (harus bisa menghasilkan uang). Artinya, komodifikasi merupakan proses menjadikan sesuatu apapun untuk dapat "dijual". Alhasil, terjadi pemilahan gender yang ketat telah membawa eksklusifitas perempuan sebagai sosok lain (asing). "Kelainan” tersebut telah mendorong 
Jurnal Pemikiran Sosiologi Volume 1 No.1, 2012

Derajad S Widhyharto

Demokrasi dan Komodifikasi Kesehatan Perlindungan Kesehatan Bagi Perempuan

budaya kesehatan komersil dalam pelayanan kesehatan perempuan, layaknya sebuah slogan yang secara spontan diungkapkan salah satu petugas Puskesmas di Kota Madiun kepada seorang pasien perempuan yang kemudian ditirukan kembali olehnya "jika ingin sehat, ya, berani bayar". Hal tersebut memperlihatkan semakin kentalnya dialektika materialisme, tak pelak berbagai obatobatan, produk susu kaleng dengan formulasi susu perempuan hamil berbagai macam jenis lainnya sengaja diciptakan. Dengan mengatasnamakan kesehatan perempuan mengkonsumsinya merupakan sebuah keharusan.

Melihat fakta yang terjadi di lapangan, proses demokratisasi pelayanan kesehatan perempuan hamil dan melahirkan yang diserahkan sepenuhnya pada pasar justru melahirkan ketimpangan sosial dengan semakin tidak optimalnya pelayanan kesehatan bagi perempuan hamil dan melahirkan karena kondisi ekonomi perempuan. Kondisi tersebut memunculkan asumsi demokrasi telah termodifikasi yang menempatkan pelayanan kesehatan perempuan hamil dan melahirkan hanya sebagai obyek pasar. Dengan situasi seperti itu, maka bisa dipastikan partisipasi yang akan muncul adalah partisipasi pasif. Partisipasi dimana modernisasi di bidang pelayanan kesehatan, obatobatan, dan susu formula sebagai produk perusahaan farmasi sebagai sebuah keharusan yang tidak bisa ditolak. Kemudian hal itu menjadi life style, membentuk pola hidup di kalangan perempuan hamil dan melahirkan, misalnya, bahwa susu formula lebih baik dari ASI. Susu formula memiliki kandungan-kandungan gizi yang sesuai dengan perkembangan bayi.
Fakta di lapangan menunjukan hal itu seperti yang diakui Ibu Hanum (bukan nama sebenarnya), pengurus Ikatan Bidan Indonesia Cabang Kota Madiun bahwa telah terjadi perubahan pola pengasuhan dan menyusui oleh perempuan hamil maupun pasca melahirkan. Fenomena susu kaleng dan dot buatan telah memaksa perempuan hamil dan melahirkan di Kota Madiun untuk menggunakannya, meskipun informasi ASI eksklusif lebih baik untuk meningkatkan kesehatan si anak, seringkali perempuan hamil dan melahirkan di Kota Madiun lebih tertarik menggunakan kecanggihan teknologi menyusui tersebut. Bahkan sangat yakin dengan menyerahkan sepenuhnya pertumbuhan si anak dengan mengkonsumsi formula susu instan buatan pabrik.

Uraian tersebut diperkuat dengan data pemberian ASI eksklusif pada bayi usia 0-4 tahun di Kota Madiun saat itu yang menyatakan bahwa dari jumlah 2.697 bayi, setengahnya saja yakni 1.801 bayi atau $66.78 \%$ bayi di Kota Madiun yang diberi ASI eksklusif. Kondisi tersebut mengindikasikan masih cukup banyak bayi yang belum diberi ASI eksklusif. Ini semakin membuktikan telah terjadi perubahan pola asuh dan status gizi bayi, tentu saja perubahan tersebut berpengaruh pada penurunan gizi bayi dan anak. Bagaimana bisa menolak jika konsultasi Dokter kandungan atau Bidan mensyaratkan konsumsi susu buatan pabrik. Sebagai ilustrasi; Harian Jawa Pos (16/07/04) menginformasikan pendapat seorang Dokter lokal, bahwa susu yang harus dikonsumsi ibu hamil berbeda dengan susu yang diminum ibu biasa (tidak hamil). Ada tiga nutrisi yang menjadi persyaratan mutlak susu diminum oleh ibu hamil. Nutrisi tersebut meliputi kalori, mineral, AA (asam linoleat) plus DHA 
Jurnal Pemikiran Sosiologi Volume 1 No.1, 2012

Derajad S Widhyharto

Demokrasi dan Komodifikasi Kesehatan Perlindungan Kesehatan Bagi Perempuan

(docosahexaenoic acid). "Untuk mineral dibutuhkan kalsium, natrium, zat besi serta asam folat," katanya. Sebab, ketiga nutrisi tersebut sangat berperan pada kesehatan ibu hamil. Sekaligus membantu perkembangan organ janin saat organogenesis (pembentukan organ). "Sehingga, sangat disarankan minum susu saat hamil muda."

Partisipasi pasif merupakan partisipasi ketidakberdayaan perempuan hamil dan melahirkan di tengah serbuan perusahaan farmasi yang "memaksa" mereka untuk menggunakan produk perusahaan kesehatan tersebut. Sekali lagi, demokrasi dalam konteks ini telah termodifikasi dalam pelayanan kesehatan perempuan hamil dan melahirkan yang tidak memberikan pilihan lain selain "kebebasan" memilih produk-produk yang dikeluarkan perusahaan farmasi.

Dalam wacana demokrasi dan demokratisasi, Indonesia merupakan salah satu negara yang tunduk pada mekanisme pasar. Dengan kata lain, Indonesia menganut liberalisme dimana kapitalisme pasar bebas dan hak-hak individu menjadi acuan dalam setiap geraknya. Studi kasus pelayanan kesehatan perempuan hamil dan melahirkan di Kota Madiun membuktikan itu. Sebagaimana sudah disampaikan di atas, maka tidak bisa disangkal jika pelayanan kesehatan di Indonesia, khususnya di Kota Madiun jauh dari optimal. Pelayanan kesehatan tidak berpihak pada perempuan terutama perempuan miskin. Asumsi bahwa modernisasi dan pembangunan akan menyejahterakan rakyat, jauh dari harapan. Kesejahteraan rakyat sebagaimana yang diamanatkan konstitusi adalah wacana kosong

11 Lihat Ibrahim, Rustam, Hubungan Demokrasi dan Bisnis Menurut Paham Neoliberal dan Demokrasi Sosial 2007: h.6. seperti menabur garam di laut. Negara yang seharusnya menyejahterakan dan melindungi rakyat adalah utopia ketika peran negara hanya sebagai penjaga keamanan dan ketertiban. Dalam konteks pelayanan kesehatan perempuan hamil dan melahirkan, demokrasi Indonesia berjalan ke arah yang sebaliknya. Liberalisme dalam bidang kesehatan merupakan kutub berbeda dari demokrasi sosial dan pembangunan inklusif yang memberi ruang bagi obyektifitas kualitas perlindungan dan pelayanan kesehatan perempuan hamil dan melahirkan. Peran dan fasilitasi negara merupakan bentuk reformasi terhadap kapitalisme untuk menghilangkan ketidakadilan yang ditimbulkannya dan mewujukan sosialisme melalui cara-cara demokratis dan evolutif. ${ }^{11}$ Demokrasi mengakui dan menerapkan pasar bebas, tapi di pihak lain, terdapat kepercayaan bahwa demokrasi mampu menyelesaikan persoalan-persoalan yang muncul dari kapitalisme yang tidak terkendali. ${ }^{12}$ Dengan kata lain, negara masih memegang peran melindungi dalam pelayanan publik (public services). Di Indonesia, demokrasi yang termodifikasi tidak memungkinkan terjadinya kondisi pelayanan ideal yang difasilitasi negara. Dalam konteks walfare state proses mutualisasi Fraser diartikan sebagai berkembangnya peran konsumen perempuan menuju transformasi menjadi klien negara yang pasif. ${ }^{13}$ Lalu secara bersamaan kapitalisme memperkecil kesetaraan peran perempuan terhadap laki-laki sebagai warga negara. Kondisi tersebut bisa dipastikan akan memperbesar "lingkaran setan" kapitalisasi negara.

\footnotetext{
12 Ibid.h.7

${ }^{13}$ Lihat Bohman, James, Beyond, Distributive Justice and Struggles for Recognition Freedom, 2002: h.267-276.
} 
Jurnal Pemikiran Sosiologi Volume 1 No.1, 2012

Derajad S Widhyharto

Demokrasi dan Komodifikasi Kesehatan Perlindungan Kesehatan Bagi Perempuan

Sebagaimana yang terjadi di negara berkembang seperti Indonesia, jika negara yang memberi kesejahteraan kepada seluruh rakyatnya melalui berbagai tunjangan saja masih juga bisa mengelabui perempuan seperti dalam proses mutualisasi di atas. Maka dengan mengatasnamakan krisis dan status negara berkembang, pemerintah belum bisa berbuat banyak untuk memperjuangkan hak kesehatan perempuan. Jangankan proses mutualisasi, tunjangan kesehatan maupun prioritas pelayanan dan perlindungan kesehatan perempuan saja masih sulit direalisasikan. Wacana gender mainstreaming ternyata tidak cukup mendorong dan memberi tekanan dalam berbagai pembuatan kebijakan. Alhasil adalah berbagai siasat kebijakan sengaja dilakukan untuk mendapatkan pengakuan dan formalitas program pembangunan kesehatan perempuan.

\section{Penutup}

Demokrasi dengan berbagai eksesnya, di satu sisi membawa dampak yang baik. Kesempatan untuk masyarakat agar lebih berkembang dalam bidang sosial, ekonomi dan politik terbentang lebih luas. Namun di sisi lain, dalam studi kasus pelayanan kesehatan perempuan hamil dan melahirkan di Kota Madiun, telah meminggirkan dan menjadikan perempuan sebagai obyek dari pelayanan kesehatan itu sendiri. Kompetisi, pastisipasi dan kebebasan hanya terjadi di wilayah kapital yang dipegang oleh perusahaan-perusahaan farmasi yang keterlibatannya diperkuat oleh negara dengan dalih peningkatan pendapatan daerah (PAD). Karena perempuan adalah obyek, maka mereka berdiri diluar lingkaran kapital itu. Perempuan merupakan sub ordinat dan penerima dampak dari kapitalisme di bidang pelayanan kesehatan tanpa bisa melakukan apa-apa. Mereka tidak berdaya atas kesehatan diri mereka sendiri. Kesehatan mereka sudah ditentukan dalam kaidah-kaidah yang telah diterbitkan oleh perusahaan farmasi dalam propaganda mereka yang sistematis. Jadi jika kita melihat kasus Bunga dalam gambaran yang sesungguhnya terjadi di Kota Madiun yang diuraikan di atas, sesungguhnya kita melihat ketidakmampuan negara dalam melindungi dan memberikan pelayanan kesehatan bagi perempuan hamil dan melahirkan. Sebab negara telah invalid dan tidak punya kekuatan untuk melindungi dan memberikan pelayanan kesehatan dalam sistem pasar yang digemakan akan membawa kesejahteraan bagi rakyat. Setelah memahami kasus Bunga, lalu pelajaran apa yang diperoleh, apakah setelah bertahun-tahun berlalu sudah ada perbaikan dan berubah menuju perlindungan kesehatan yang lebih baik atau sebaliknya, belum ada perubahan?

\section{Daftar Pustaka}

Bohman, James. 2002. "Beyond Distributive Justice and Struggles for RecognitionFreedom,Democracy", Saint Louis University, European Journal of Political Theory, SAGE Publications Ltd, Los Angeles, London, New Delhi and Singapore, ISSN: 1474-8851, 6(3) 267-276.

Ibrahim, Rustam, 2007, "Hubungan Demokrasi dan Bisnis Menurut Paham Neoliberal dan Demokrasi Sosial, Makalah "Bisnis dan Demokrasi” diselenggarakan Yayasan Melania, Jeneponto. Tidak dipublikasikan.

Mansour Fakih, 2001, Analisis Gender dan Transformasi Sosial. Yogyakarta: Pustaka Pelajar

Nugroho, Riant, D. 2003. Kebijakan Publik, formulasi, implementasi dan evaluasi. Jakarta: Elex Media Komputindo. 
Jurnal Pemikiran Sosiologi Volume 1 No.1, 2012

Derajad S Widhyharto

Demokrasi dan Komodifikasi Kesehatan Perlindungan Kesehatan Bagi Perempuan

Preston, P.W. 1996. Development Theory An Introduction. Blackwell Publisher.

Pratikno, 1998, Fungsi-Fungsi Pemerintahan, Makalah "Pendalaman Materi Bidang Tugas DPRD” (tidak dipublikasikan), Yogyakarta.

Sorensen, Georg. 2003. Demokrasi dan Demokratisasi, Proses dan Prospek dalam Sebuah Dunia yang Sedang Berubah, Yogyakarta: Pustaka Pelajar.

Sukmaningsih, Indah dkk, 2003, Mengorganisir Konsumen Kesehatan Reproduksi. Jakarta: YLKI.

UU/Regulasi/Publikasi Khusus:

Perda No.14. Tahun 2003 Tentang Retribusi Profesi Kesehatan

Profil Dinas Kesehatan Kota Madiun Tahun 20002001

Profil Dinas Kesehatan Kota Madiun Tahun 20012002

Profil Dinas Kesehatan Kota Madiun Tahun 20022003

Profil Data SUSENAS 2001

Propeda Kota Madiun Tahun 2001-2005

UU No.10. Tahun 1992 Tentang Perkembangan Kependudukan dan Pembangunan Keluarga Berencana

UU No.23. Tahun 1992 Tentang Kesehatan

\section{Surat Kabar:}

Kompas, 13/05/05.

Kompas, 15/12/2003

Kompas, 14/07/2003

Kompas, 6/08/05

Jawa Pos, 16/07/04

\section{Wawancara:}

Dinas Kesehatan Kota Madiun, tanggal 23 Februari 2004.

Ikatan Bidan Indonesia, Cab. Kota Madiun, tanggal 7 Februari 2004 